\title{
AN EMPIRICAL EXAMINATION OF THE IMPACT OF LOCUS OF CONTROL ON INVESTOR BEHAVIORAL BAISES
}

\author{
Anu Singh Lather \\ Vice Chancellor, Ambedkar University, Delhi, India \\ Shilpa Jain \\ University School of Management Studies, Guru Gobind Singh IP University, India \\ Shivani Anand \\ University School of Management Studies, Guru Gobind Singh IP University, India
}

\begin{abstract}
The purpose of this paper is to examine the relationship between locus of control and behavioral biases (emotional and cognitive) in investor decision-making. Our research involved three stages. In the first stage, we undertook an exhaustive review of the existing literature to identify 20 commonly occurring biases in investor decision making. In the second stage, we individually studied each bias to identify and develop instruments for measuring these biases in investor decision making. During the pilot phase, based on exploratory factor analysis, some of these biases were clubbed together. Confirmatory factor analysis was conducted to develop a validated instrument for measuring these biases. In stage three, the finalized questionnaire along with Levenson's locus of control was administered on a group of investors across the country and 618 responses were received. The results of this study have revealed underlying patterns within biases based on the Individual Control, Powerful others and Chance control. Investors with a high score on individual control showed significant differences and had a stronger inclination to being prone to Mental Accounting, Self Control, Framing, Illusion of Control, Regret Aversion, Recency, Availability, Anchoring and Adjustment, Optimism, Confirmation, Overconfidence and Endowment related biases. Further, Individuals having higher Chance control scores had a higher inclination to having cognitive dissonance within their investment decision making. Thus, results from this study helped understand the impact of locus of control on investor biases and preferences to facilitate the identification of an investor's predisposition towards particular investing choices. This also serves as a mechanism to identify whether investors have an underlying inclination towards specific biases in investment decision making. This identification can facilitate remediation or corrective actions on part of the investor based on whether he has an internal or an external locus of control.
\end{abstract}


Keywords: Behavioural Finance, Cognitive and emotional biases, locus of control, investor decision making.

Cite this Article: Anu Singh Lather, Shilpa Jain, Shivani Anand, An Empirical Examination of the Impact of Locus of Control on Investor Behavioral Baises, International Journal of Management (IJM), 11 (1), 2020, pp. 97-106.

http://iaeme.com/Home/issue/IJM?Volume=11\&Issue $=1$

\section{INTRODUCTION}

Behavioral finance, as an academic subject is an interdisciplinary area that leverages on the concepts of economics, finance, sociology and psychology to examine the implications and outcomes of financial decisions made by individual investors and traders in the market. In the efficient market scenario, the investor expected to operate rationally making optimal decisions based on perfect information while carefully evaluating costs and benefits of each of their investment choices (Becker, 2013). However, Richard Thaler (Winner of the 2017 Nobel Prize) identified that investors suffer from myopic loss aversion (Benartzi \& Thaler, 1995), the tendency of investors to compare the performances of their investment portfolios from the perspective of avoiding a possible loss rather than from the perspective of potential gains. This revealed a strong deviation from the efficient market hypothesis (Shleifer, 2000) which is based on rational investors with well-defined subjective utility functions that they have to maximize to ensure that even if there are some investors who are not rational; their trading activities either will cancel each other out or be arbitraged by other rational investors.

Further, Kahneman, 2003, identified that investors rely on heuristics developed from an individual's life experiences, preferences and perceptions while evaluating investment choices. This meant that investor decisions were not fully rational and based on their preconceived notions and perceptions. Additionally, evidence from the stock market revealed that investor decision making is influenced by psychological biases and cognitive errors (Choi, Laibson and Metrick, 2000).

Thus, the knowledge of behavioral finance becomes pivotal to financial planners and counselors and investors to understand their financial goals, objectives, and behavioral patterns including the errors in financial decision-making (Chatterjee \& Goetz, 2015). Our present study aims to examine the impact of locus of control on behavioral biases and preferences to identify patterns in investor decision making.

\section{LITERATURE REVIEW}

\subsection{Behavioral Biases}

Comprehensive Psychological research has documented a range of biases affecting investor decision making. These biases sit deep within our psyche and as fundamental parts of human nature. Empirical evidence in the behavioral finance literature show that individuals do not behave rationally. Barberis and Thaler (2003) provide a good summary of models that try to explain the equity premium puzzle, excess volatility, excessive trading, stock return predictability using both Prospect Theory of Kahneman and Tversky (1979) and beliefs. Sunstein et al. (2002) support the view that markets are not efficient and investor biases affect security prices substantially. De Long et al. (1990), Shleifer \& Vishny (1997), Barberis \& Huang (2001), Hirshleifer (2001) and Subrahmanyam (2007) show that investors are not rational or markets may not be efficient and hence prices may significantly deviate from fundamental values due to existence of irrational investors. Based on the existing literature review, our research identified a group of 21 predominant behavioral biases existent in investor decision making summarized in the table below: - 
Table 1 Containing the Behavioral Biases as identified by literature review

\begin{tabular}{|c|c|c|c|}
\hline Sno & Bias Name & General Description & Key Researchers \\
\hline 1 & $\begin{array}{l}\text { Prediction Overconfidence } \\
\text { Bias (Cognitive) }\end{array}$ & $\begin{array}{l}\text { The confidence intervals that an investor may assign } \\
\text { to their investment predictions, when asked to do so, } \\
\text { are too narrow. }\end{array}$ & $\begin{array}{l}\text { Clarke, Statman, } \\
2000\end{array}$ \\
\hline 2 & $\begin{array}{l}\text { Certainty Overconfidence } \\
\text { Bias (Cognitive) }\end{array}$ & $\begin{array}{l}\text { Investors simply feel too confident about their } \\
\text { predictions of future returns for a given asset class or } \\
\text { investment. }\end{array}$ & $\begin{array}{l}\text { Clarke, Statman, } \\
2000\end{array}$ \\
\hline 3 & $\begin{array}{l}\text { Representativeness Bias } \\
\text { (Cognitive) }\end{array}$ & $\begin{array}{l}\text { The representativeness heuristic takes one } \\
\text { characteristic of a company and extends it to other } \\
\text { aspects of the firm. }\end{array}$ & $\begin{array}{l}\text { Kahneman } \& \\
\text { Tversky, } 1974\end{array}$ \\
\hline 4 & $\begin{array}{l}\text { Anchoring \& Adjustment } \\
\text { Bias (Cognitive) }\end{array}$ & Initial Arbitrary Value and Make Adjustments. & $\begin{array}{l}\text { Northcraft, Neale } \\
\text { (1987) }\end{array}$ \\
\hline 5 & $\begin{array}{l}\text { Cognitive Dissonance Bias } \\
\text { (Cognitive) }\end{array}$ & $\begin{array}{l}\text { When new information conflicts with existing beliefs, } \\
\text { contrary views may be accepted. }\end{array}$ & Festinger, 1957. \\
\hline 6 & $\begin{array}{l}\text { Availability Bias } \\
\text { (Cognitive) }\end{array}$ & $\begin{array}{l}\text { Salient Events / Available information cause one to } \\
\text { relate favourably or unfavourably. }\end{array}$ & $\begin{array}{l}\text { Odean, Barber } \\
2002\end{array}$ \\
\hline 7 & $\begin{array}{l}\text { Self Attribution Bias } \\
\text { (Cognitive) }\end{array}$ & $\begin{array}{l}\text { People may attribute failures to situational factors and } \\
\text { successes to dispositional factors. }\end{array}$ & $\begin{array}{l}\text { Dunn, } 1989, \\
\text { Odean, barber, } \\
2001\end{array}$ \\
\hline 8 & $\begin{array}{l}\text { Illusion of Control Bias } \\
\text { (Cognitive) }\end{array}$ & $\begin{array}{l}\text { We like to pretend that we can influence the resulting } \\
\text { score by varying the force with which we throw a } \\
\text { dice. }\end{array}$ & Fellner, 2009 \\
\hline 9 & $\begin{array}{l}\text { Conservatism Bias } \\
\text { (Cognitive) }\end{array}$ & $\begin{array}{l}\text { A mental process by which people cling to prior } \\
\text { information / views. }\end{array}$ & Hirshleifer, 2001 \\
\hline 10 & $\begin{array}{l}\text { Ambiguity Aversion Bias } \\
\text { (Cognitive) }\end{array}$ & $\begin{array}{l}\text { People Avoid Uncertain Probability Distributions. } \\
\text { Aversion Changes Based on Perceived Competency at } \\
\text { Assessing Relevant Distribution with Preference for } \\
\text { Familiarity. }\end{array}$ & $\begin{array}{l}\text { Graham, Harvey, } \\
\text { Huang, } 2006\end{array}$ \\
\hline 11 & $\begin{array}{l}\text { Endowment Bias } \\
\text { (Emotional) }\end{array}$ & Value an asset more which they own it. & List, 2003 \\
\hline 12 & $\begin{array}{l}\text { Self Control Bias } \\
\text { (Emotional) }\end{array}$ & $\begin{array}{l}\text { Tendency to consume today at the expense of } \\
\text { tomorrow. }\end{array}$ & $\begin{array}{l}\text { Thaler, Shefrin, } \\
1988 .\end{array}$ \\
\hline 13 & $\begin{array}{l}\text { Optimism Bias } \\
\text { (Emotional) }\end{array}$ & Unrealistic View of Personal Abilities / Prospects & Kahneman, 2000 \\
\hline 14 & $\begin{array}{l}\text { Mental Accounting Bias } \\
\text { (Cognitive) }\end{array}$ & $\begin{array}{l}\text { Mental accounting refers to our tendency to "put } \\
\text { things in boxes" and track them individually. }\end{array}$ & $\begin{array}{l}\text { Huang, Barberis, } \\
2001\end{array}$ \\
\hline 15 & $\begin{array}{l}\text { Confirmation Bias } \\
\text { (Cognitive) }\end{array}$ & $\begin{array}{l}\text { Selective perception that emphasizes already existing } \\
\text { views. }\end{array}$ & $\begin{array}{l}\text { Statman, Fisher, } \\
2000\end{array}$ \\
\hline 16 & Hindsight Bias (Cognitive) & Feeling that "I knew it all along". & $\begin{array}{l}\text { Cooper, } \\
\text { Gutierrez, } \\
\text { Marcum, } 1998\end{array}$ \\
\hline 17 & $\begin{array}{l}\text { Loss Aversion Bias } \\
\text { (Emotional) }\end{array}$ & $\begin{array}{l}\text { Investors do not like losses and often engage in } \\
\text { mental gymnastics to reduce their psychological } \\
\text { impact. }\end{array}$ & $\begin{array}{l}\text { Kahneman, } \\
\text { Tversky, } 1979\end{array}$ \\
\hline 18 & Recency Bias (Cognitive) & $\begin{array}{l}\text { Recent Events cause one to relate favourably or } \\
\text { unfavourably. }\end{array}$ & Montier, 2003 \\
\hline 19 & $\begin{array}{l}\text { Regret Aversion Bias } \\
\text { (Emotional) }\end{array}$ & $\begin{array}{l}\text { Investors do not like to make mistakes. } \\
\text { Rather than being unable to decide among attractive } \\
\text { alternatives, they are worried that they may pick the } \\
\text { incorrect alternative. }\end{array}$ & $\begin{array}{l}\text { Statman, } \\
\text { Sheffrin, } 2000\end{array}$ \\
\hline 20 & Framing Bias (Cognitive) & Tendency to respond based on context & $\begin{array}{l}\text { Kahneman, } \\
\text { Tversky, } 1979\end{array}$ \\
\hline 21 & $\begin{array}{l}\text { Status Quo Bias } \\
\text { (Emotional) }\end{array}$ & Tendency to choose options which suggest no change & $\begin{array}{l}\text { Samuelson, } \\
\text { Zeckhauser, } 1988\end{array}$ \\
\hline
\end{tabular}

Our research further built on the literature review to prepare likert scale instruments for measuring each of these biases.

\subsection{Locus of Control}

Locus of control is a term in psychology, which identifies how people perceive their environment and the causes of their success or rewards in their lives (Lefcourt, 1968). These 
phenomena showed that some people believe that things outside of themselves are the reasons for their success or failures while others believed that they are in control of their lives and control factors that cause success or failures.

Julian B. Rotter, 1954 identified this concept as Locus of Control and it has since become an important aspect of personality studies. Locus of control refers to the extent to which individuals believe that they can control events that affect them. Individuals with a high internal locus of control believe that events result primarily from their own behavior and actions. Those with a high external locus of control believe that powerful others, fate, or chance primarily determine events. An individual's locus of control reflect how an individual perceives what happens to him. The more we have learned to expect connections between our actions and outcomes, the more internal we are while the less we expect such links, the more external we are. If we are more internal, we tend to view ourselves as able to influence the course of our lives, if we are more external, we tend to view our lives as governed by forces beyond our control. Those with a high internal locus of control have better control of their behavior, tend to exhibit more political behaviors, and are more likely to attempt to influence other people than those with a high external locus of control; they are more likely to assume that their efforts will be successful. They are more active in seeking information and knowledge concerning their situation.

In our present study, locus of control was measured using Levenson (1981) scale. The scale consists of three subscales; Individual control, powerful others, and chance. High scores on both the powerful others- and the chance subscales reflect an external locus of control orientation whereas high scores on individual control reflect an internal locus of control.

These scales were used as independent measures of locus of control, as recommended by (Levenson, 1981). Individual control measured using eight items on a likert scale of 1 to 5 . The scale measured to what extend one feels control over outcomes in their life. External locus of control (i.e., powerful others) was also measured with eight items (e.g., "I feel like what happens in my life is mostly determined by powerful people") for powerful others and another eight items for Chance control (e.g, I feel that that outcomes in my own life are dependent upon luck or chance). Responses were given on a 5-point scale from 1 (Strongly disagree) to 5 (Strongly agree).

\section{RESEARCH METHODOLOGY}

\subsection{Initial Pilot}

The initial part of the research involved identification of predominant behavioral biases across existing literature and prepare instruments to measure these biases. For preparing the instruments to measure these biases, a preliminary questionnaire was prepared with 97 questions and responses from 425 investors was collected under the pilot study as per recommendation (Bryman and Bell, 2007) to ensure that a questionnaire is sufficient and to reduce errors (Stern, McDaniel, \& Gates, 1992). Factor analysis was conducted and five biases namely Endowment, Status, Loss, Hindsight, and conservatism were clubbed together. and the questionnaire was reduced to 71 questions.

\subsection{Final Questionnaire}

After the factor analysis, the finalized questionnaire consisted of 71 questions for measuring the behavioral biases was framed. This questionnaire, combined with Levenson's locus of control questionnaire comprising 24 questions and demographic questions (Gender, Region of the country, Age group, level of education, financial literacy, years of experience, income group, marital status and market portfolio) making a total of 104 questions was administered on 750 investors and 618 complete responses were received. 


\subsection{Research Design}

This research was an empirical study to identify the relationship between locus of control subscales namely, individual control, powerful others and chance control on behavioral biases in investor decision making. For the study, a 4 X 4 X 2 X 3 X 4

Factorial design was used. The regional differences amongst individual investors, namely north, south, east and west, along with age, educational background with special emphasis on a financial background was considered. Under each unit, the years in trading from 0-1, 1-3, 35 and above 5 years of experience were used for the study.

Sample Size

Based on a $4 \times 4 \times 2 \times 3 \times 4$ factorial design, a minimum of 480 individual investors sample size was required. For the present study our sample size is 618 investors.

\section{RESULTS AND FINDINGS}

Some interesting results were observed using the findings of the results.

The analysis below shows that there is a significant difference in cognitive biases of investors having high and low internal locus of control. Similarly, there is a significant difference in cognitive biases of investors having high and low chance control. There was no significant difference observed in the investor biases having high and low powerful others.

Table 2 Showing the impact of internal locus of control and chance control on the behavioural biases

\begin{tabular}{|c|c|c|c|c|c|c|}
\hline Source & $\begin{array}{c}\text { Dependent } \\
\text { Variable }\end{array}$ & $\begin{array}{l}\text { Type III } \\
\text { Sum of } \\
\text { Squares }\end{array}$ & df & $\begin{array}{c}\text { Mean } \\
\text { Square }\end{array}$ & $\mathbf{F}$ & Sig. \\
\hline \multirow{17}{*}{$\begin{array}{l}\text { Internal } \\
\text { Locus } \\
\text { of } \\
\text { Control }\end{array}$} & Mental accounting & 143.421 & 2 & 71.71 & 218.818 & .000 \\
\hline & Self Control & 164.288 & 2 & 82.144 & 171.905 & .000 \\
\hline & Framing & 155.943 & 2 & 77.972 & 224.885 & .000 \\
\hline & Illusion of Control & 110.433 & 2 & 55.216 & 171.161 & .000 \\
\hline & Representativeness & 157.395 & 2 & 78.698 & 343.899 & .000 \\
\hline & Recency & 164.055 & 2 & 82.027 & 336.651 & .000 \\
\hline & Availability & 146.104 & 2 & 73.052 & 189.708 & .000 \\
\hline & $\begin{array}{c}\text { Anchoring \& } \\
\text { Adjustment }\end{array}$ & 187.026 & 2 & 93.513 & 327.206 & .000 \\
\hline & Ambiguity & 161.884 & 2 & 80.942 & 288.335 & .000 \\
\hline & Self Attribution & 123.756 & 2 & 61.878 & 169.187 & .000 \\
\hline & Regret Avoidance & 145.811 & 2 & 72.906 & 228.375 & .000 \\
\hline & $\begin{array}{c}\text { Prediction } \\
\text { Overconfidence }\end{array}$ & 159.084 & 2 & 79.542 & 342.768 & .000 \\
\hline & $\begin{array}{c}\text { Certainty } \\
\text { Overconfidence }\end{array}$ & 164.529 & 2 & 82.264 & 329.869 & .000 \\
\hline & Optimism & 150.982 & 2 & 75.491 & 303.184 & .000 \\
\hline & $\begin{array}{l}\text { Endowment, } \\
\text { Status, Loss, } \\
\text { Hindsight, } \\
\text { conservatism }\end{array}$ & 139.287 & 2 & 69.644 & 283.353 & .000 \\
\hline & Confirmation & 152.77 & 2 & 76.385 & 278.006 & .000 \\
\hline & $\begin{array}{l}\text { Cognitive } \\
\text { Dissonance }\end{array}$ & 163.45 & 2 & 81.725 & 263.924 & .000 \\
\hline \multirow{6}{*}{$\begin{array}{l}\text { Chance } \\
\text { Control }\end{array}$} & Mental accounting & 12.396 & 2 & 6.198 & 18.913 & .000 \\
\hline & Self Control & 20.739 & 2 & 10.37 & 21.701 & .000 \\
\hline & Framing & 14.947 & 2 & 7.474 & 21.556 & .000 \\
\hline & Illusion of Control & 9.2 & 2 & 4.6 & 14.259 & .000 \\
\hline & Representativeness & 11.872 & 2 & 5.936 & 25.94 & .000 \\
\hline & Recency & 16.87 & 2 & 8.435 & 34.618 & .000 \\
\hline
\end{tabular}




\begin{tabular}{|c|c|c|c|c|c|}
\hline Availability & 13.989 & 2 & 6.995 & 18.164 & .000 \\
\hline $\begin{array}{c}\text { Anchoring \& } \\
\text { Adjustment }\end{array}$ & 18.786 & 2 & 9.393 & 32.867 & .000 \\
\hline Ambiguity & 13.007 & 2 & 6.503 & 23.167 & .000 \\
\hline Self Attribution & 8.363 & 2 & 4.181 & 11.433 & .000 \\
\hline Regret Avoidance & 16.091 & 2 & 8.046 & 25.202 & .000 \\
\hline $\begin{array}{c}\text { Prediction } \\
\text { Overconfidence }\end{array}$ & 11.572 & 2 & 5.786 & 24.934 & .000 \\
\hline $\begin{array}{c}\text { Certainty } \\
\text { Overconfidence }\end{array}$ & 13.514 & 2 & 6.757 & 27.094 & .000 \\
\hline Optimism & 14.021 & 2 & 7.011 & 28.156 & .000 \\
\hline $\begin{array}{l}\text { Endowment, } \\
\text { Status, Loss, } \\
\text { Hindsight, } \\
\text { conservatism }\end{array}$ & 12.115 & 2 & 6.057 & 24.645 & .000 \\
\hline Confirmation & 13.923 & 2 & 6.961 & 25.336 & .000 \\
\hline $\begin{array}{c}\text { Cognitive } \\
\text { Dissonance }\end{array}$ & 12.388 & 2 & 6.194 & 20.003 & .000 \\
\hline
\end{tabular}

A scrutiny of means table show that investors with high internal locus of control are significantly higher than investors with average and low internal locus of control on investor biases like Mental Accounting, Self Control, Illusion of control, Representativeness, Recency, Availability, Anchoring and Adjustment, Ambiguity, Self-Attribution, Regret aversion, Prediction and Certainty Overconfidence, Optimism and Endowment.

The investors with high internal locus of control are significantly higher than investors with average and low internal locus of control on framing bias. Also, the investors with low internal locus of control are significantly higher than investors with average internal locus of control on framing.

Further, the investors with high internal locus of control are significantly higher than investors with average and low internal locus of control on the confirmation bias. Also, the investors with average internal locus of control are significantly higher than the investors with low internal locus of control on the confirmation bias.

Finally, the investors with low internal locus of control are significantly higher on cognitive dissonance bias as compared to investors with average and low internal locus of control. Also, the investors with average internal locus of control are significantly higher than the investors with low internal locus of control on the cognitive dissonance bias.

Table 3 Showing the impact of behavioural biases on investors with high, medium and low internal locus of control

\begin{tabular}{|l|c|c|c|}
\hline \multicolumn{1}{|c|}{ Dependent Variable } & $\begin{array}{c}\text { High } \\
\text { Internal } \\
\text { control }\end{array}$ & $\begin{array}{c}\text { Average } \\
\text { Internal } \\
\text { Control }\end{array}$ & $\begin{array}{c}\text { Low } \\
\text { Internal } \\
\text { Control }\end{array}$ \\
\hline Mental accounting & $4.2286_{\mathrm{a}}$ & $1.9657_{\mathrm{b}}$ & $2.2488_{\mathrm{b}}$ \\
\hline Self Control & $4.2913_{\mathrm{a}}$ & $2.0076_{\mathrm{b}}$ & $2.0838_{\mathrm{b}}$ \\
\hline Framing & $4.2787_{\mathrm{a}}$ & $1.9172_{\mathrm{b}}$ & $2.4375_{\mathrm{c}}$ \\
\hline Illusion of Control & $4.0702_{\mathrm{a}}$ & $2.112 \mathrm{~b}_{\mathrm{b}}$ & $1.8438_{\mathrm{b}}$ \\
\hline Representativeness & $4.2351_{\mathrm{a}}$ & $1.8328_{\mathrm{b}}$ & $1.9063_{\mathrm{b}}$ \\
\hline Recency & $4.2202_{\mathrm{a}}$ & $1.869_{\mathrm{b}}$ & $1.8438_{\mathrm{b}}$ \\
\hline Availability & $4.3538_{\mathrm{a}}$ & $2.0406_{\mathrm{b}}$ & $1.7925_{\mathrm{b}}$ \\
\hline Anchoring \& Adjustment & $4.2183_{\mathrm{a}}$ & $1.7157_{\mathrm{b}}$ & $1.6425_{\mathrm{b}}$ \\
\hline Ambiguity & $4.1394_{\mathrm{a}}$ & $1.7121_{\mathrm{b}}$ & $1.6875_{\mathrm{b}}$ \\
\hline Self Attribution & $4.1936_{\mathrm{a}}$ & $2.1138_{\mathrm{b}}$ & $2.1255_{\mathrm{b}}$ \\
\hline Regret Avoidance & $4.1191_{\mathrm{a}}$ & $1.9741_{\mathrm{b}}$ & $1.8438_{\mathrm{b}}$ \\
\hline Prediction Overconfidence & $4.2409_{\mathrm{a}}$ & $1.9076_{\mathrm{b}}$ & $1.99_{\mathrm{b}}$ \\
\hline
\end{tabular}




\begin{tabular}{|l|l|l|l|} 
Certainty Overconfidence & $4.2713_{\mathrm{a}}$ & $1.8328_{\mathrm{b}}$ & $1.7188_{\mathrm{b}}$ \\
\hline Optimism & $4.1032_{\mathrm{a}}$ & $1.8052_{\mathrm{b}}$ & $1.8438_{\mathrm{b}}$ \\
\hline $\begin{array}{l}\text { Endowment, Status, Loss, Hindsight, } \\
\text { conservatism }\end{array}$ & $4.1923_{\mathrm{a}}$ & $2.0035_{\mathrm{b}}$ & $1.7925_{\mathrm{b}}$ \\
\hline Confirmation & $4.1702_{\mathrm{a}}$ & $1.860 \mathrm{~b}_{\mathrm{b}}$ & $1.5313_{\mathrm{c}}$ \\
\hline Cognitive Dissonance & $1.7947_{\mathrm{a}}$ & $3.875_{\mathrm{b}}$ & $4.2328_{\mathrm{c}}$ \\
\hline
\end{tabular}

A scrutiny of means table show that investors with low chance control are significantly higher than investors with average and high chance control on investor biases like Mental Accounting, Framing, Illusion of control, Representativeness, Recency, Availability, Anchoring and Adjustment, Ambiguity, Self-Attribution, Regret aversion, Prediction and Certainty Overconfidence, Optimism, Endowment, Confirmation and Cognitive Dissonance. Also, investors with average chancel control are significantly higher than investors with Mental Accounting, Framing, Illusion of control, Representativeness, Recency, Availability, Anchoring and Adjustment, Ambiguity, Self-Attribution, Regret aversion, Prediction and Certainty Overconfidence, Optimism, Endowment, Confirmation and Cognitive dissonance biases. Finally, investors with low chance control are significantly higher than average and low chance control on the Framing bias.

Table 4: Showing the impact of behavioural biases on investors with high, medium and low chance control

\begin{tabular}{|l|l|l|l|}
\hline \multicolumn{1}{|c|}{ Dependent Variable } & $\begin{array}{c}\text { High } \\
\text { Chance } \\
\text { control }\end{array}$ & $\begin{array}{c}\text { Average } \\
\text { Chance } \\
\text { Control }\end{array}$ & $\begin{array}{c}\text { Low } \\
\text { Chance } \\
\text { Control }\end{array}$ \\
\hline Mental accounting & $3.1246_{\mathrm{a}}$ & $3.5334_{\mathrm{b}}$ & $4.3750_{\mathrm{c}}$ \\
\hline Self Control & $3.1822_{\mathrm{a}}$ & $3.5612_{\mathrm{a}}$ & $4.7525_{\mathrm{b}}$ \\
\hline Framing & $3.0505_{\mathrm{a}}$ & $3.6456_{\mathrm{b}}$ & $4.4375_{\mathrm{c}}$ \\
\hline Illusion of Control & $3.0934_{\mathrm{a}}$ & $3.4725_{\mathrm{b}}$ & $4.1250_{\mathrm{c}}$ \\
\hline Representativeness & $3.0644_{\mathrm{a}}$ & $3.4973_{\mathrm{b}}$ & $4.1250_{\mathrm{c}}$ \\
\hline Recency & $3.0593_{\mathrm{a}}$ & $3.4959_{\mathrm{b}}$ & $4.4375_{\mathrm{c}}$ \\
\hline Availability & $3.2014_{\mathrm{a}}$ & $3.6492_{\mathrm{b}}$ & $4.4175_{\mathrm{c}}$ \\
\hline Anchoring \& Adjustment & $3.0011_{\mathrm{a}}$ & $3.4262_{\mathrm{b}}$ & $4.4275_{\mathrm{c}}$ \\
\hline Ambiguity & $2.9293_{\mathrm{a}}$ & $3.4148_{\mathrm{b}}$ & $4.1250_{\mathrm{c}}$ \\
\hline Self Attribution & $3.1641_{\mathrm{a}}$ & $3.5632_{\mathrm{b}}$ & $4.2500_{\mathrm{c}}$ \\
\hline Regret Avoidance & $3.0253_{\mathrm{a}}$ & $3.4876_{\mathrm{b}}$ & $4.4063_{\mathrm{c}}$ \\
\hline Prediction Overconfidence & $3.0758_{\mathrm{a}}$ & $3.5505_{\mathrm{b}}$ & $4.1500_{\mathrm{c}}$ \\
\hline Certainty Overconfidence & $3.0720_{\mathrm{a}}$ & $3.5206_{\mathrm{b}}$ & $4.2813_{\mathrm{c}}$ \\
\hline Optimism & $2.9659_{\mathrm{a}}$ & $3.3997_{\mathrm{b}}$ & $4.3438_{\mathrm{c}}$ \\
\hline $\begin{array}{l}\text { Endowment, Status, Loss, Hindsight, } \\
\text { conservatism }\end{array}$ & $3.0999_{\mathrm{a}}$ & $3.5279_{\mathrm{b}}$ & $4.2713_{\mathrm{c}}$ \\
\hline Confirmation & $3.0518_{\mathrm{a}}$ & $3.4341_{\mathrm{b}}$ & $4.0938_{\mathrm{c}}$ \\
\hline Cognitive Dissonance & $1.7500_{\mathrm{a}}$ & $2.5096_{\mathrm{b}}$ & $3.0088_{\mathrm{c}}$ \\
\hline
\end{tabular}

This trend demonstrates that the key reason for biases in investor decision making may be rooted in the internal locus control subscale as a part of the locus of control variable. Further, higher locus of control also demonstrates a very low propensity towards cognitive dissonance which illustrates a unique feature of the cognitive dissonance bias regarding decision making since the individuals with higher cognitive dissonance bias have difficulty in decision making which is opposite of individuals with high internal locus of control who demonstrate a clear belief in their decisions. 


\section{LIMITATION OF THE RESEARCH}

The present research had some shortcomings since it is based on only one aspect of personality namely, locus of control and its sub scales and their relationship with investment biases. This also means there is a research gap, which provides for scope for future research to identify and link other personality factors with investment related behavioral biases. Further, our present research has only focused on investors in India. This is also a research gap since we can further extend this research to other countries and their investors to identify and compare the impact of personality on investment related behavior.

\section{CONCLUSIONS}

Investors, financial planners and investment advisors play a pivotal role in understanding the goals and needs of investors. One of their key concerns is identifying and understanding the investment behaviors and errors thereof. The existence of fundamental deviations in economic decisions reflects the presence of systematic errors. It is, therefore, imperative for investors, investment advisors and policy makers to understand the presence of these errors (investor biases or preferences) to ensure rectification of these errors and ensure that investment plans are not undermined by the existence of these anomalies.

The present study attempts to identify these interrelationships between behavioral biases and preferences and one key personality trait namely locus of control. Our research further explored the impact of the various subscales of locus of control, namely, internal locus of control, powerful others and chance control on behavioral biases and the results have shown that there exists a significant difference in cognitive biases of investors based on internal locus of control and chance control, whereas there is no significant difference in investor biases based on powerful others. Further, an interesting finding was observed wherein investors with high internal locus of control demonstrated low cognitive dissonance bias and investors with a low internal locus of control demonstrated high cognitive dissonance bias. Also, a high internal locus of control was related to higher cognitive biases in investors except cognitive dissonance. Thus, an investors internal locus of control and chance control have shown a higher level of the behavioral biases.

Thus, the research endeavors to enable investors, investment advisors and policy makers to identify these deviations based on the locus of control with a view to correct them and safeguard investors from errors in investment decision making.

\section{REFERENCES}

[1] Barber, B. and Odean, T, The Internet and the Investor. Journal of Economic Perspectives, 15(1), 2001, pp.41-54.

[2] Barber, B. and Odean, T, Online Investors: Do the Slow Die First?. Review of Financial Studies, 15(2), 2002, pp.455-488.

[3] Barberis, N. and Huang, M, Mental Accounting, Loss Aversion, and Individual Stock Returns. The Journal of Finance, 56(4), 2001, pp.1247-1292.

[4] Barberis, N. and Thaler, R, A Survey of Behavioral Finance. SSRN Electronic Journal, 2002

[5] Chatterjee, S. and Goetz, J, Behavioral Finance. Client Psychology, 2018, pp.11-18.

[6] McN., G. and Becker, G, The Economic Approach to Human Behavior. Population and Development Review, 4(3), 1978, p.525.

[7] McN., G. and Becker, G, The Economic Approach to Human Behavior. Population and Development Review, 4(3), 1978, p.525. 
[8] Bell, E. and Bryman, A, the Ethics of Management Research: An Exploratory Content Analysis. British Journal of Management, 18(1), 2007, pp.63-77.

[9] Benartzi, S. and Thaler, R, Myopic Loss Aversion and the Equity Premium Puzzle. The Quarterly Journal of Economics, 110(1), 1995, pp.73-92.

[10] Choi, J., Laibson, D. and Metrick, A, Does the Internet Increase Trading? Evidence from Investor Behavior in 401(k) Plans. SSRN Electronic Journal, 2000

[11] Clarke, R. and Statman, M, The DJIA Crossed 652,230. The Journal of Portfolio Management, 26(2), 2000, pp.89-92.

[12] Cooper, M., Gutierrez, R. and Marcum, W, On the Predictability of Stock Returns in Real Time. SSRN Electronic Journal, 1998

[13] De Long, J., Shleifer, A., Summers, L. And Waldmann, R, The Size and Incidence of the Losses from Noise Trading. The Journal of Finance, 44(3), 1989, pp.681-696.

[14] Dunn, D, Demonstrating a Self-Serving Bias. Teaching of Psychology, 16(1), 1989, pp.21-22.

[15] Fellner, G, Illusion of Control as a Source of Poor Diversification: Experimental Evidence. Journal of Behavioral Finance, 10(1), 2009, pp.55-67.

[16] Festinger, L, A Study of Thinking.J. S. Bruner, J. J. Goodnow, G. A. Austin. American Journal of Sociology, 63(2), 1957, pp.231-232.

[17] Fisher, K. and Statman, M, Cognitive Biases in Market Forecasts. The Journal of Portfolio Management, 27(1), 2000, pp.72-81.

[18] Graham, J., Harvey, C. and Huang, H, Investor Competence, Trading Frequency, and Home Bias. SSRN Electronic Journal, 2006

[19] Hirshleifer, D, Investor Psychology and Asset Pricing. SSRN Electronic Journal, 2001

[20] Kahneman, D, A Psychological Perspective on Economics. American Economic Review, 93(2), 2003, pp.162-168.

[21] Kahneman, D, New Challenges to the Rationality Assumption. Legal Theory, 3(2), 1997, pp.105-124.

[22] Kahneman, D. and Tversky, A, Prospect Theory: An Analysis of Decision under Risk. Econometrica, 47(2), 1979, p.263.

[23] Lefcourt, H., Lewis, L. and Silverman, I, Internal vs. External Control of Reinforcement and Attention in a Decision-Making Task1. Journal of Personality, 36(4), 1968, pp.663682.

[24] Manatap Berliana Lumban Gaol, Imam Ghozali, Fuad, Time Budget Pressure, Auditor Locus of Control and Reduced Audit Quality Behavior. International Journal of Civil Engineering and Technology, 8(12), 2017, pp. 268-277

[25] List, J, Does Market Experience Eliminate Market Anomalies?. The Quarterly Journal of Economics, 118(1), 2003, pp.41-71.

[26] Levenson, H, Levenson Locus of Control Scales. PsycTESTS Dataset, 1972

[27] Montier, J, Darwin's Mind: The Evolutionary Foundations of Heuristics and Biases. SSRN Electronic Journal, 2003

[28] Dr. Murlidhar Panga, Anjali Malpani (Singi) and Ajay Malpani, A Study of Factors Affecting Investors' Decision Towards Making Investments in Financial Market, Journal of Management, 5(3), 2018, pp. 169-177 
[29] Northcraft, G. and Neale, M, Experts, Amateurs, and Real Estate: An Anchoring-andAdjustment Perspective on Property Pricing Decisions. Organizational Behavior and Human Decision Processes, 39(1), 1987, pp.84-97.

[30] Rotter, J. B, Social Learning and Clinical Psychology, 1954, doi:10.1037/10788-000

[31] Samuelson, W. and Zeckhauser, R, Status Quo Bias in Decision Making. Journal of Risk and Uncertainty, 1(1), 1988, pp.7-59.

[32] Shefrin, H. and Statman, M, Behavioral Portfolio Theory. The Journal of Financial and Quantitative Analysis, 35(2), 2000, p.127.

[33] Biju Thomas Muttath and Dr. Assissi Menachery, Investor Expectations on 'Return' and 'Trust' on IPO Grading: An Empirical Analysis. International Journal of Management, 7(3), 2016, pp. 172-184

[34] Shleifer, A, Professional Arbitrage. Inefficient Markets, 2000, pp 89-111. doi:10.1093/0198292279.003.0004

[35] Shefrin, H. and Thaler, R, The Behavioral Life-Cycle Hypothesis. Economic Inquiry, 26(4), 1988, pp.609-643.

[36] Shleifer, A, and Vishny, R. W, A Survey of Corporate Governance. The Journal of Finance, 52(2), 1997, pp 737-783. doi:10.1111/j.1540-6261.1997.tb04820

[37] Dr. Ayan Chattopadhyay and Pawan Gupta, An Interval Entropic Estimation of Consumer Priority in Multi-Attribute Behavioural Environment -A Case Study of Financial Investment Instruments in an Urban Vista. International Journal of Management, 8 (6), 2017, pp. 136-151

[38] Stern, B., McDaniel, C. and Gates, R, Contemporary Marketing Research. Journal of Marketing Research, 29(3), 1992, p.379.

[39] Sunstein, C, Kahneman, D, Schkade, D. and Ritov, I, Predictably Incoherent Judgments. Stanford Law Review, 54(6), 2002, p.1153.

[40] Tversky, A. and Kahneman, D, Judgment under Uncertainty: Heuristics and Biases. Science, 185(4157), 1974, pp.1124-1131.

[41] Subrahmanyam, K, Book Reviews. British Journal of Developmental Psychology, 25(2), 2007, pp 323-324. doi:10.1348/026151007x192655 